\title{
The Effect of IFRS Convergence, Independent Commissioner Proportion and Commissioners Board Size on Accounting Conservatism Level
}

\author{
Yunina $^{1}$, Nur Afni Yunita ${ }^{1}$, Murhaban ${ }^{1}$, Sri Mulyati ${ }^{1}$, Dy Ilham Satria ${ }^{1}$, Mutia Dewi ${ }^{2}$, \\ Wahyuddin Albra ${ }^{3}$, Apridar Abdurrahman ${ }^{3}$, and Henry Aspan ${ }^{4}$ \\ \{yunina@unimal.ac.id, murhaban@unimal.ac.id, srimulyati@unimal.ac.id\} \\ ${ }^{1}$ Department of Accounting, Universitas Malikussaleh, Aceh, Indonesia \\ ${ }^{2}$ Graduation of Accounting Department, Universitas Malikussaleh, Aceh, Indonesia \\ ${ }^{3}$ Department of Management, Universitas Malikussaleh, Aceh, Indonesia \\ ${ }^{4}$ Department of Management, Universitas Pembangunan Panca Budi, Medan, Indonesia
}

\begin{abstract}
As for the objective of this study was to know the partial influence of IFRS convergence, proportion of independent commissioner, and size of the board of commissioners to level of accounting conservatism. The number of sample used in this research were 32 observation at Food and Beverages companies listed on Indonesian Stock Exchange from 2012-2015. The sample of this research was taken using purposive sampling. The method used in data analyzing was multiple linear regression analysis. The result indicated that partially, IFRS convergence influenced positively and significantly to the level of accounting conservatism with significance level 0.015. Proportion of independent commissioner did not influence on the level of accounting conservatism with significance level 0.438 . While size of commissioner board influenced negatively and significantly on the level of accounting conservatism with significance level 0.049 . The researcher suggested that (1) management should consider exactly on the influencing factors on accounting conservatism, (2) further researcher should improve the other factors influencing on the level of accounting conservatism such as leverage, bonus plan, debt covenant, political cost, etc.
\end{abstract}

Keywords: IFRS convergence, proportion of independent commissioner, size of the board of commissioner, level of accounting conservatism

\section{INTRODUCTION}

One of the principles in accounting is accounting conservatism. Zeghal and Lahmar [1] stated that conservatism is useful for many decision makers.

Hartanto [2] defined conservatism as a principle in financial reportingintended to recognizeand measure assets and profits that is carefully conducted due to uncertain economic and business activities.This conservatism is implemented because of the uncertain future economic circumstances. In this case, the level of accounting conservatism applied by each company is varied. Zhang [3] argued that IFRS adoption will reduces the problem about 
agency conflict between management and shareholder in information asimetry case. Thus, [4] argued that the application of the conservatism principles also expects companies not to mark up their business results so that creditors and investors as the external parties using financial statements are not deceived by into the high figures of the assets. In addition, the conservatism principle also aims to ensure that the financial statements do not mislead the users in decision making.

Since IFRS was adopted by some countries in the world, make the topic about IFRS become trending topic for researcher [1].

The fair value principle employed in IFRS use more estimation to reasonably assess the assets. While, the estimation made by managers often leads to the problems that has been the focus of accounting conservatism so far. [5] said that with the IFRS will reduces the using of conservatism. But André [6] reported that until now, conservatism or prudence still as a part of the IASB's and FASB's conceptual frameworks.

The implementation of conservative accounting in the financial statements of companies is also influenced by the corporate governance mechanism. For conducting corporate governance well, must be observed about the characteristic of commissioner board. There are two characteristics of the board of commissioners chosen in this study, namely: the proportion of independent commissioners and the size of the board of commissioners.

The characteristics of the board of commissioners related to the proportion of independent commissionersshould be addressed to promote independence in the supervision process of the company performance. The independent commissioners enable a stricter supervision conducted by the board of commissioners which in turn will tend to demand more conservative accounting to habituate corporate mangers in order not to do a fraud in preparing accounting information that cause users to be at a disadvantage. Furthermore, Watts (2003) in [7] contended that the conservatism in accounting is beneficial to avoid the opportunistic behavior of the managers related to the contracts that use financial statements as the contract medium.

The size of the board must be observed by company. Because the number of members of commissioner board related to cost and the way of supervision [8]. The bigger size of the board of commissioners will lead to a more specific task for each member of the board of commissioners as there will be a more specific committee in supervising the company. A broader specialization indicates a more effective supervision so that the accounting application demanded by the board of commissioners is more conservative. Therefore, the number of members of the board of commissioners should be based on the company needs for a more effective supervision [9].

\section{LITERATURE REVIEW}

\subsection{Conservatism}

Conservatism is a principle in financial reporting intended to recognize and measure assets and profits that is carefully conducted to face the uncertainty in future [10]. The conservatism concept states that in the uncertain circumstance, the company manager will determine the accounting treatment or action based on the circumstance, expectations of events, or the results considered less profitable. The implication of this concepts in the accounting principle is that accounting recognizes possible cost or loss but not immediately recognizes future income or profit despite its high probability [11] 
Conservatism is an important characteristics of company accounting system that can assist the board of commissioners to reduce the agency cost and improve the quality of financial statements which in turn will improve the value of the company and its stock price (Ahmed and Duellman, 2007 in [9]. Conservatism is the most influencing principle on the accounting assessment. However, conservatism is also a controversial concept. Some studies reported that conservative accounting is not beneficial yet some others reported otherwise.

\subsection{IFRS Convergence}

The convergence of IFRS (International Financial Reporting Standards)is one of the agreement of Indonesian government as the member of G-20 in Washington DC on 15th November 2008. The convergence to IFRS means standard merging and integration, interpretation and framework in the preparation and presentation of financial statements adopted from the current IFRS to be used and directed to a single destination.

There are various changes of financial statements in IFRS, such as the change of accounting method to fair value from historical cost. IFRS loads more principle than rule [6]. The concern of fair value that may eliminate the conservatism to obtain profit from accounting assessment of the company based on the manager estimation is unreasonable. The fair value principle used in IFRS mainly uses estimation to reasonably assess the assets. However, the estimation created by the manager causing the issues that has been the focus of conservatism recently.

Zeghal and Lahmar [1] argued that the absence of conservatism as one of the obstacles mentioned in the conceptual framework of IFRS does not mean the conservatism principle is lost. This is because the accountant has often used conservatism in accounting practice. This raises doubts concerning the absence of the long-standing principle of conservatism in Indonesia even though the IFRS principle has been established. Based on the opinions above, so the hyphotesis is:

$\mathrm{H}_{1}$ : IFRS convergence has an influence on the level of accounting conservatism

\subsection{Proportion of Independent Commissioner}

In the corporate governance mechanism, the board of commissioners play a crucial role in preventing conflict related to agency. The board of commissioners consists of the commissioncers from outside affiliated party, known as the independent commissioners, and affiliated commissioners

Usually, the members of commissioners board are not affiliated with shareholders controlling, board director's member and the other board of commissioners and the company itself in both business and family-like relationship. The board of commissioners are not allowed to be involved in management task nor representing the company for the transaction with the third party. One of main function of the independent commissioners is to run a more independent supervision function for the company management framework. The existence of the independent commissioners can balance the strength of the management party (especially CEO) in managing company through the supervision function [9].

Independent commissioners are an important part of a company. Wardhani [9] stated that the high the proportion of independent commissioners relative to the total number of commissioners related to the high the level of accounting conservatism (measured by the market size). The higher the proportion of independent commissioners in a company will indicate a strong board of commissioners; the higher the level of conservatism demanded due to a more qualified financial information. When the proportion of independent commissioners 
is smaller, the supervision conducted will be weaker leading to the company manager having the opportunity to employ more aggressive and less conservative accounting principles [12].

Indriawati, Ayu, and Sari [13] claimed that the proportion of independent commissioners has no significant effect on the level of accounting conservatism.

This is due to the lack of ideal supervision from the board of independent commissioners as the tool of management supervision. In addition, the independent commissioners are only existing to fulfil formal requirements or regulations instead of up holding a good corporate governance. Based on the theories reviewed, the following hypothesis is proposed.

$\mathrm{H}_{2}$ : Proportion of independent commissioners have an influence on accounting conservatism.

\subsection{Size of Commissioner Board}

The size of the board of commissioners is the exact number of the members of the board in performing their duties. In Indonesia, good corporate governance role has managed about justification of commissioner board member with the company complexity with a great attention to achieve the effectiveness in decision making.

Yunos, Ahmad, and Sulaiman [11] said that small or large of board size is related to accounting conservatism at least influenced on accounting conservatism level. [14] indicated that the companies with strong board of commissioners as corporate governance mechanisms requires a higher level of conservatism compared to the weaker one. While Indrayati [15] found that the size of the board of commissioners has no significant impact on the level of accounting conservatism.

Ahmed and Duellman [12] stated that the size of the board of commissioners is related to an audit committee who performs its tasks more specifically. The larger size of the board of commissioners is associated with a more specific task for each member of the board of commissioners as there are more specialized committees to supervise the company. A wider specialization can also indicate a more effective supervision.

So, to achieve an effectiveness for company, very important observed about small or large size of member. The bigger the board of commissioners indicates a greater capacity of the board in conducting supervision and the increasing use of the conservative accounting. Based on the reviews, the following hypothesis is proposed.

$\mathrm{H}_{3}$ : Size of commissioners' board have an influence on the level of accounting conservatism

\section{METHOD}

The following are the variables used in this research

1. Independent variables:

a. IFRS Convergence

It is measured using dummy scale. The company that has implemented IFRS is scored

1 and the those that has not yet IFRS is scored 0 .

b.The proportion of IndependentCommissioners (INDEP_COM)

The following formula is used to measured The proportion of IndependentCommissioners:

$$
\text { INDEP_COM }=\frac{\text { Independent Commissioner }}{\text { Number of Commissioners }}
$$


c. The size of commissioners' board (UDK)

This measure is indicated by the number of the members of commissioners' board in a company including both independent and non-independent commissioners. The data related to independent commissioners is obtained from both company annually report and the announcement published by Indonesian Stock Exchange (BEI).

UDK $=$ Number of Commissioners

2. Dependent variable: accounting conservatism The following formula is used to measure conservatism:

Notation:

$$
\text { Con_Acc }=\frac{\mathrm{NI}+\mathrm{Dep}-\mathrm{CF}}{\mathrm{TA}}
$$

Con_Acc $=$ The level of accounting conservatism

NI = Profit before extraordinary items

Dep $=$ Depreciation and amortization cost

$\mathrm{CF}=$ Operating cash flow

$\mathrm{TA}=$ The total asset

Food and Beverage companies are there in BEI (2012-2015) wasused as population in this study. Researcher was obtained about 14 companies.Sampling method used is the purposive sampling that employing certain criteria in choosing the object. The criteria are presented as follows.

1. All of firms in food and beverage sectors are there in BEI in 2012-2015. The food and beverage company chosen to obtain the similar characteristics of the companies.

2. The company did not incure any losses during the period $2012-2015$.

3. The company has complete data of the year 2012 to 2015

Eight companies meet the above criteria and were chosen as the sample. The total observations were 32 samples.

The researcher was used purely secondary data for this study. The data gathered using documentation technique including:(a) the financial statements of the Food and Beverage companies listed and published in the Indonesian Stock Exchange through www.idx.co.id and (b) reviewing literature including accounting journal and related books.

The acceptance or rejection of hypothesis can determine with using multiple regression. The regression equation model of the analysis is presented as follows:

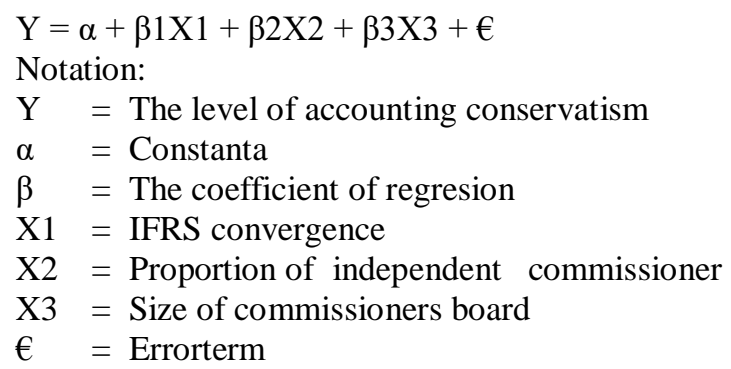




\section{RESULT AND DISCUSSION}

\subsection{Descriptive Statistics}

Table 1. Descriptive Statistics

\begin{tabular}{|c|c|c|c|c|c|}
\hline & $\mathrm{N}$ & Min & Max & Mean & Std. Deviation \\
\hline CON_ACC & 32 & -0.1980 & 0.1670 & -0.004734 & 0.0700960 \\
\hline IFRS & 32 & 0 & 1 & 0.94 & 0.246 \\
\hline COM_IDP & 32 & 0.3300 & 0.4300 & 0.384375 & 0.0365608 \\
\hline UKD & 32 & 3 & 8 & 4.94 & 1.664 \\
\hline $\begin{array}{l}\text { Valid N } \\
\text { (listwise) }\end{array}$ & 32 & & & & \\
\hline
\end{tabular}

Table 1 shows that the mean of accounting conservatism (CON_ACC) of Food and Beverages companies listed in the Indonesian Stock Exchange from 2012 to 2015 is -0.004734 $(\mathrm{SD}=0.070096)$.

IFRS convergence is measured using dummy. Based on the 32 sample, it is indicated that the mean of IFRS convergence of Food and Beverages companies listed in the Indonesian Stock Exchange from 2012 to 2015 is 0.94 ( $\mathrm{SD}=0.246$ ).

The measurement of independent commissioner proportion (COM_IDP) is comparison between the total of independent commissioner and the total of commissioner board. The mean that achieved by firm to the proportion of independent commissioners is 0.384375 $(\mathrm{SD}=0.0365608)$.

The size of the board of commissioners (UDK) is measured by the total number of members of commissioners' board in the company. The mean of the size of the board of commissioners of Food and Beverages companies listed in the Indonesian Stock Exchange from 2012 to 2015 is 4.94 ( $\mathrm{SD}=1.664)$.

\subsection{Multiple Linear Regression Analysis}

The results of regression analysis is showed in table 2

Table 2. Regression Analysis Results

\begin{tabular}{|c|c|c|c|}
\hline Variables & B & $\mathrm{T}_{\text {value }}$ & $\begin{array}{c}\text { Sig } \\
(\mathrm{t})\end{array}$ \\
\hline Constanta & -0.146 & -1.160 & 0.256 \\
\hline $\begin{array}{l}\text { IFRS } \\
\text { Convergence }\left(X_{1}\right)\end{array}$ & 0.121 & 2.593 & 0.015 \\
\hline $\begin{array}{l}\text { Proportion } \\
\text { of Independent } \\
\text { Commissioner }\left(\mathrm{X}_{2}\right)\end{array}$ & 0.277 & 0.786 & 0.438 \\
\hline $\begin{array}{l}\text { Size of } \\
\text { Commissioner } \\
\text { Board }\left(\mathrm{X}_{3}\right)\end{array}$ & -0.016 & -2.062 & 0.049 \\
\hline $\mathrm{t}_{\text {table }} \quad=2.04841$ & & & \\
\hline
\end{tabular}


According to regression result in table 2, the formula of regression analysis is:

$$
\mathrm{Y}=-0.146+0.121 \mathrm{X} 1+0.277 \mathrm{X} 2-0.016 \mathrm{X} 3+€
$$

\subsection{Analysis of IFRS Convergence on Accounting Conservatism Level}

The results of partial significant test (t-test) shows that IFRS convergence has an influence on the level of accounting conservatism as indicated by the level of significanceof $0.015(\mathrm{p}<0.015)$. Therefore, this study accepts $\mathrm{H}_{1}$, indicating that IFRS convergence has a positive impact on the level of accounting conservatism.

It can be concluded that even though IAI has established PSAK-IFRS converge on 1 January 2012, there is possibility for the company to apply accounting conservatism in their financial reporting as conservatism is culture of accounting. IFRS is the new principle of accounting policy in Indonesia. Therefore, accountants have not been able to fully eliminate the conservatism principle. It takes a long process to eliminate accounting conservatism. The finding of this study is in line with [16] reported that no difference changes of accounting conservatism before and after IFRS mandatory adoption period.

The result of this finding is against the finding of [1] reporting that there is a decreasing on accounting conservatism after adoption period of IFRS, where various change occurs in IFRS financial statements such as the change of accounting method used previously, namely historical cost that has been shifted to fair value. The fair value principle put a great emphasis on relevance which is contrary to the conservatism principle emphasizing on the reliability. Thus, when a company applies IFRS, it tends to be less conservative.

\subsection{Analysis of Independent Commissioners Proportion on Accounting Conservatism Level}

The result of partial significant test (t-test) shows that the proportion of independent commissioners has no influence of the level of accounting conservatism indicating by the significance level of $\mathrm{p}=0.438(\mathrm{p}>0.05)$. Therefore, $\mathrm{H}_{2}$ is rejected. This means that the proportion of independent commissioners has no impact on the level of accounting conservatism

This is due to the strong control of the company's founders and majority shareholders which in turn pressing the position of independent commissioners. This means that independent commissioners are no longer independent in their tasks. Managers can easily conduct some manipulation such as marking up report so that the conservatism principle is no longer applied by the company.

The finding of this study is in line with [7] who reported that the proportion of independent commissioners has no significant influence on the level of accounting conservatism. This is due to the lack of ideal supervision by the independent commissioners as the tool of management supervision. In addition, the independent commissioners are only existing for the sake of formal requirement or regulation instead of good corporate governance.

\subsection{Analysis of Commissioners Board Size on Accounting Conservatism Level}

The result of partial significant test (t-test) indicates that the size of the board of commissioners influences the level of accounting conservatism indicating by the level of significance of $0.049(\mathrm{p}<0.05)$. Therefore, this study accepts the $\mathrm{H}_{3}$, indicating that the size of the board of commissioners have a negative influence on the level of accounting conservatism. 
The negative influence can be interpreted as the bigger the size of commissioners' board the lower the level of accounting conservatism. This indicates that the bigger size of the board of commissioners may lead to communication and coordination issues in supervising the management performance which in turn causing the decrease of the board of commissioners' capacity to control the management. A weak supervision and control of managers results in managers easily manipulating profit. Therefore, there should be regulation regarding the ideal size of the board of commissioners in a company. The right board of commissioners tends to demand for accounting conservatism to avoid the opportunistic behavior of managers.

This study is in line with [12] who found that the size of commissioner board as a part of directors characteristic can help firm to solve the agency problem. The company financial reporting is less conservative despite the bigger number of the board of commissioners.

The finding of this study is in contrast with the study conducted by [7]reporting that size of commissioner board has no significant effect to accounting conservatism that usually exercise by corporate managers in Malaysia who wants to take an advantage of accrual method in accounting.

\section{Conclusions}

The result indicated that partially, IFRS Convergence influenced positively and significantly to the level of accounting conservatism. Proportion of independent commissioner did not influence on the level of accounting conservatism. While size of commissioner board influenced negatively and significantly on the level of accounting conservatism.

\section{References}

[1] D. Zeghal and Z. Lahmar, "The Impact of IFRS Adoption on Accounting Conservatism in the European Union," Int. J. Account. Financ. Report., vol. 6, no. 1, p. 127, 2016.

[2] T. Hartanto, "Rev. Integr. Bus. Econ. Res. Vol 4(1) 176," Rev. Integr. Bus. Econ., vol. 4, no. 1, pp. 176-183, 2014.

[3] J. Zhang, "The Effect of IFRS Adoption on Accounting Conservatism - New Zealand Perspective Jian Zhang A dissertation submitted to Auckland University of Technology in partial fulfillment of the degree of Master of Business Faculty of Business and Law Primary Superv," Dissertation, 2011.

[4] R. Lim, "Are corporate governance attributes associated with accounting conservatism?," Account. Financ., vol. 51, no. September 2010, pp. 1007-1030, 2011.

[5] N. Hellman, “Accounting Conservatism under IFRS,” Account. Eur., vol. 5, no. 2, pp. 71-100, 2008.

[6] P. André, "Accounting Conservatism in Europe and the Impact of Mandatory IFRS Adoption : Do country, institutional and legal differences survive? About the ESSEC-KPMG Financial Reporting Centre," ESSEC Bus. Sch., vol. 30 Septemb, 2016.

[7] R. M. Yunos, "the Effect of Ownership Concentration, Board of Directors, Audit Committee and Ethnicity on Conservative Accounting: Malaysian Evidence," PhD Thesis, pp. 1-232, 2011.

[8] L. Holtz and A. Sarlo Neto, "Effects of Board of Directors' Characteristics on the Quality of Accounting Information in Brazil," Rev. Contab. Finanças, vol. 25, no. 66, pp. 255-266, 2014.

[9] R. Wardhani, "the Effect of Degree of Convergence To Ifrs and Governance System To Accounting Conservatism: Evidence From Asia," Pus. Data Ekon. Bisnis, vol. 13, no. January, pp. 0-21, 2010. 
[10] S. NM, "The Effect of Accounting Conservatism on Financial Performance Indicators in the Jordanian Insurance Companies," J. Internet Bank. Commer., vol. 21, no. 1, pp. 1-16, 2016.

[11] R. M. Yunos, S. A. Ahmad, and N. Sulaiman, "The Influence of Internal Governance Mechanisms on Accounting Conservatism," Procedia - Soc. Behav. Sci., vol. 164, no. August, pp. 501-507, 2014.

[12] A. S. Ahmed and S. Duellman, "Accounting Conservatism and Board of Director Characteristics : An Empirical Analysis," J. Account. Econ., vol. 43, pp. 411-437, 2007.

[13] F. Indriawati, D. Ayu, and P. Sari, "Proportion of the Independent Commissioners $€^{\mathrm{TM}}$ Board , Institutional Ownership and Its Characteristics Effect on Discussion of Sukarela in Annual Report ( Empirical Study of Manufacturing Companies Listed on BEI," Res. J. Financ. Account., vol. 8, no. 12, pp. 55-64, 2017.

[14] S. Suleiman, "Coporate Governance Mechanisms and Accounting Conservatism," J. Manag. Policies Pract., vol. 2, no. 2, pp. 113-127, 2014.

[15] M. R. Indrayati and D. DALJONO, "Pengaruh karakteristik dewan komisaris terhadap tingkat konservatisme akuntansi." UNIVERSITAS DIPONEGORO, 2010.

[16] E. F. de Sousa, “Adoption of IFRS in Brazil : Effects on Accounting Conservatism," J. Educ. Res. Account., vol. 10. No.2, pp. 133-144, 2016. 